\title{
THE TRANSLATION SHIFT AND ACCURACY ANALYSIS OF MUSEUM MACAN'S CAPTION
}

\author{
Denny \\ Denny.2014ude032@civitas.ukrida.ac.id \\ Universitas Kristen Krida Wacana \\ Siegfrieda A. S. Mursita Putri \\ Siegrieda@ukrida.ac.id \\ Universitas Kristen Krida Wacana
}

\begin{abstract}
Museum MACAN is the first museum that exhibit modern art. Museum MACAN has Indonesia-English caption in their Instagram account in order to promote their collection. This study investigates translation shift occurs in Museum MACAN's Instagram caption and the accuracy of their translation. The translation shift is used to produces accurate translation. This study uses Catford's theory about translation shift (1964) and the accuracy based on ATA Rubric Assessment. The data were twenty five Museum MACAN's Instagram captions. The collected data were analysed, in order to fine the translation shift and accuracy of their caption. There are three evaluators to rate the accuracy of the captions. The first evaluator is the writer of this study; the second evaluator is a student of management from Universitas Negeri Jakarta who works as freelance translator more than two years, the third evaluator is a professional translator who has been in translation field for twenty five years. The result of the translation shift analysis is there are five shifts occur in Museum MACAN's Instagram captions. The most used shift is structure shift. It shows that the use of shift helps writer or translator adjusts word into appropriate sentence from source text to target text.
\end{abstract}

Keywords: Accuracy, ATA rubric assessment, Instagram, Museum MACAN, Translation shift

\section{INTRODUCTION}

Museum MACAN is the first museum that exhibits contemporary art collection in Indonesia. It's target is locals and foreigners. Museum MACAN has Instagram account to promote their collection by creating Indonesia-English captions. Museum MACAN chooses to use human translation instead of machine translation that is provided by Instagram. This is a fact because the machine translation that is provided by Instagram would provide a different translated text if the "see translation" button was clicked. A translation that is produced by machine is limited in term of flexibility because the produced translation is programmed. translation from machine translation.

However, analysing the translation accuracy alone is not enough. Analysing what are shifted during the process of translation from Indonesian language into English in order to create an accurate translation is also important. As such, this study decides to analyse the translation shifts that occurred in the translated
Museum MACAN's Instagram captions. The term "translation shift" is introduced by Catford (1964). Translation shift is used to reach accurate translation (Sipayung, 2018). The higher the accuracy, the more accurate and precise a translation is. However, making an accurate translation is not an easy task for translators. Larson (1998) states that the accuracy of translation refers to the precise understanding of the source language and the transfer of the message, as accurate as possible into the target language. Catford (1964) stressed that in the process of translation there should be an appropriate equivalence between SL and TL. The same concept between translation shift and accuracy which focuses on translation result that accurately transfers into TL. Also, translation shift is a tool that help translator to produce accurate translation. This study choose to investigates translation shift occurs in Museum MACAN Instagram captions and Accuracy of their captions. This study uses translation shift theory based on Catford (1964) and the ATA rubric instrument by American Translator 
Association (ATA).ATA rubric assessment is used for grading translation text with high standard in America. From the ATA's experiences in translation field more than fifty years and has many members in ninety countries that makes ATA becomes valid and reliable (Williams, 2013). Furthermore, ATA rubric has four scales and dimensions to determine the accuracy of a translated text such as meaning, terminology, grammar and spelling. ATA has higher standard than other rubric such as Nababan's instrument that only has three scales. Because of this reason, the researcher wants to use ATA rubric assessment in this study. Therefore, the translation result can be well delivered and understood by English speakers all around the world. This study is also participating in introducing Indonesian cultures to English speakers and international community by conducting a research about Indonesian culture and giving information to readers. For further researches, this study is expected to give additional knowledge, in order to familiarize with accuracy of texts and other option in analysing accuracy. For translator, this study gives information about translation shift in Indonesia - English caption and gives option to analyse accuracy of text by using ATA rubric assessment. For Museum MACAN, this study also can be profitable to Museum MACAN to know the level of the accuracy that they provide on their Instagram captions. For Indonesia, this study gives benefits in introducing Indonesian culture by conducting a research of Indonesian culture.

\section{FINDING AND DISCUSSION}

This study was a qualitative study because this study used text as the data. This study was a library research because this study analyzed the captions and used content analysis. This is also a primary research. The data were twenty five captions from Museum MACAN's Instagram caption. The data were related to exhibition. The captions that related to the exhibitions had more possibility to attract visitors and to raise their interest of Museum MACAN. In order to make the result more objective and reliable, this study uses three evaluators to evaluate the data. The first evaluator was the researcher of this study. The second evaluator was a freelance translator. The third evaluator was a professional translator who has been in translation field more than twenty five years. The professional certified translator made the result of the analysis became more precise, valid and reliable. The most scales assessed by evaluators were represented the dimensions.

\section{Translation Shift Analysis}

Table 1Overall Result of Translation Shift Analysis

\begin{tabular}{|l|l|l|}
\hline No & Shift & Total \\
\hline 1 & Level shift & 3 \\
\hline 2 & Structure shift & 76 \\
\hline 3 & Unit shift & 25 \\
\hline 4 & Class shift & 12 \\
\hline 5 & Intra-system shift & 34 \\
\hline
\end{tabular}

There are three level shifts, seventy six structure shifts, twenty five unit shifts, twelve class shifts and thirty four intrasystem shifts. The most shift that occurs is structure shift.Catford (1964) states level shift is used to show that there is certain structure or grammatical point that occurs in the sentence. Structure shift occurs because there are different structure between Indonesia (SL) and English (TL). Unit shift occurs when there are shifts from ST that has one level to another level of lexical equivalence in TT. Class shift occurs when a word in a certain part of speech is changed to other part of speech. Intrasystem shift occurs because there is a change from singular to plural forms between ST and TT.

(1) ST: akan segera merilis

TT: is launching

Level shift is occurred in (1), the ST "akan segera merilis" is translated into TT "is launching". The translator of Museum Macan's Instagram translates the phrase "akan segera" into "is launching" because the translator wants to state about the condition that is being planned and about to be executed in the near future. This shows that the translator of the caption thinks that 
the ST "akan" is equivalent with TT "is". However, the researcher thinks that the ST "akan" is not equivalent with TT "is" because ST "akan" represents a condition that happens in the future and the equivalence of TT is "will". Therefore, the researcher concludes that (1) has grammatical change which influences the meaning of TT. This explains that the structure used is present progressive tense. In (1) the phrase "akan segera", is translated to "is launching" (to be + V-ing).

(6) ST: salah satu tokoh artistik utama.

TT: one of the central artistic figures. (SS6)

In (6), it can be seen that structure shift is occurred. There are different structures and the translator also adds some words in his/ her translation. The translator changes the structure from ST to TT. This shift is obligatory because it should follow the linguistic style. The translator adds ending "$s$ " at the end of the word "figure" because the phrase "one of the" must be followed by plural noun. In Bahasa, the word "salah satu" is defined that the noun is plural. In this example, the noun is "tokoh" but in Bahasa Indonesia structure, if there is a determiner that indicates the plural noun, then the noun is not plural too, meanwhile in English it is the opposite. Therefore, it makes the translator changes the structure to follow the linguistic rule in Indonesia. This example also can be considered as an intra-system shift if we analyze it in singular to plural changes, but the researcher only focuses analyzing this example in its structure.

(9) ST: melawan (US9)

TT: went against

In (9), the example is defined as unit shift. The ST "melawan" is considered as a word that has equivalence of TT "went against" which is considered as a verb phrase. The translator uses "went" to state that this example has already happenned in the past.This example indicates that the unit shift happens. In accordance to Catford (1964), this can happen when word level of $\mathrm{SL}$ items has rank in different TL items. This example is also the same as Alzhudy (2015) that states the changes of rank from one unit to another level. This unit shift is considered as upward rank shift because ST is considered as word and it shifts to a higher level which is a phrase in TT.

(14) ST: secara bebas

(CS14) TT: freely

In (14), the example is defined as class shift. ST "secara bebas" is classified as an adjective that has meaning "dengan tidak terikat" in (KBBI Daring, 2018), Meanwhile, TT "freely" is classified as an adverb that has meaning "without restriction" in (English Oxford Dictionaries, 2018). An adverb describes, provides or modifies more information about a verb in sentence. The word free is an adjective but when added the ending -ly, it becomes freely which classified as adverb. Therefore, the class shift happens because there are part of speech changes from adjective to adverb. The translator does class shift to make the translation result become more accurate. In accordance with Trivanti (2017) in her study, she states that class shift helps translator to produce good and readable translation.

(14) ST: papan tulis dan teks (ISS14)

TT: blackboards and texts

In (14), the example is classified as an intrasystem shift. The ST indicates singular noun while TT indicates plural noun as we can see in ST "papan tulis dan teks" and TT "blackboards and texts". The ST and TT have different meanings. If ST is translated literally then it will be "blackboard and text" without the ending " $-\mathrm{s}$ ", but the translator uses ending $-\mathrm{s}$ in his/ her translation. It can be concluded that intra-system shift occurs in this example because there is a shift from singular to plural. The translator uses ending -s in TT "blackboards and texts" to follow the non-corresponding term which is to state that the noun is plural by using ending "-s".

The use of translation shift is to help translator to reach an accurate translation which can be understood by the readers. It is in line with Alzhudy (2015) that 
Translation shift theory introduced by Catford (1964) can be used as basic theory which adequate in the translation study.

\section{Accuracy Analysis}

Table 2 Overall Result of Accuracy Analysis

\begin{tabular}{|l|l|l|l|l|}
\hline $\begin{array}{l}\text { Dimensi } \\
\text { ons }\end{array}$ & $\begin{array}{l}\text { Evaluat } \\
\text { or I }\end{array}$ & $\begin{array}{l}\text { Evaluat } \\
\text { or II }\end{array}$ & $\begin{array}{l}\text { Evaluat } \\
\text { or III }\end{array}$ & Result \\
\hline $\begin{array}{l}\text { Usefulne } \\
\text { ss }\end{array}$ & Strong & $\begin{array}{l}\text { Accepta } \\
\text { ble }\end{array}$ & Strong & $\begin{array}{l}\text { Accur } \\
\text { ate }\end{array}$ \\
\hline $\begin{array}{l}\text { Terminol } \\
\text { ogy }\end{array}$ & Strong & $\begin{array}{l}\text { Accepta } \\
\text { ble }\end{array}$ & Strong & $\begin{array}{l}\text { Accur } \\
\text { ate }\end{array}$ \\
\hline $\begin{array}{l}\text { Idiomatic } \\
\text { Writing }\end{array}$ & Strong & Strong & Strong & $\begin{array}{l}\text { Accur } \\
\text { ate }\end{array}$ \\
\hline $\begin{array}{l}\text { Target } \\
\text { Mechanic }\end{array}$ & Strong & Strong & Strong & $\begin{array}{l}\text { Accur } \\
\text { ate }\end{array}$ \\
\hline
\end{tabular}

From the Table 2, the Evaluator 1 and 3 rate the usefulness on Museum MACAN's Instagram captions as strong. Meanwhile, Evaluator 2 rates the usefulness of all captions as acceptable. It can be concluded that the usefulness of Museum MACAN's Instagram captions is accurate. The used of terminology is considered as accurate by Evaluator 1 and 3. Meanwhile, Evaluator 2 rates the used of terminology as acceptable. It can be concluded that the terminology of Museum MACAN's Instagram captions is accurate. All evaluators agree that the captions deserve to get a strong scale. It can be concluded that the Idiomatic of Museum MACAN's Instagram captions is accurate. All evaluators also agree that Museum MACAN uses grammar, spelling and punctuation correctly in their captions. Based on accuracy analysis that was done by three Evaluators, it can be concluded that the accuracy of Museum MACAN's Instagram captions is accurate.

(35) ST: "Seniman asal Meksiko, Miguel Covarrubias menciptakan karya yang mengeksplor seni, budaya, agama dan geografi Bali berjudul "Island of Bali". Lihat langsung karyanya di bagian 'Bumi, Kampung Halaman, Manusia' pada pameran "Seni Berubah. Dunia Berubah" yang digelar hingga 18 Maret 2018".

TT: "The Mexican multi-faceted artist, Miguel Covarrubias created seminal work book that explores the art, culture, religion, and geography of Bali to the world, called "Island of Bali." The painting is a part of 'Land, Home, People' section in "Art Turns. World Turns" exhibition, on display until 18 March 2018"

In (35), the Evaluator 1 has rated this caption as strong. According to ATA, the terminology of caption can be rated as strong if the translated text contains no, one inappropriate term or any errors that have minor effect on meaning. Therefore, the Evaluator 1 rates this caption as acceptable because the translated text contains a few, no inappropriate term or register choices. Any error has minor effects on meaning. The term refers to terminology that has a meaning of particle technical application in a subject of study. Meanwhile, the register refers to the use of formal word. In this caption, the term is identified in the ST "Senimal asal Meksiko" into TT "The Mexican multi-faceted Artist". The word "multi-faceted" has a meaning that the artist has expertised in many fields. It is supported by sentence "Miguel Covarrubias created seminal work book that explores the art, culture, religion, and geography of Bali." The sentence explains that Miguel Covarrubias has expertised not only in the art field but also culture, religion and geography. This translator also uses formal word in the target text. It does not show any slang words in the target text. There are types of translation shift occurred in this example. One of them is intra-system shift that is identified in ST "Seni berubah Dunia berubah" into TT "Art Turns World Turns". The translator does intra-system shift to following the non-correspondence term in English which is subject-verb agreement. If the subject is singular, in this example are the words "Art" and "World" then the verb should be singular by adding ending $-s$, in this example is word "turn" become "turns". The result of this example shows that the use of shifts helps translator to adjust his /her translation to follow the target text rule which resulting in an accurate translation. This example is in accordance with Sipayung (2018) that has the same result which translation shift helps translator to reach accurate translation. 
(56) ST: "Ahmad Sadali adalah pelopor seni abstrak modern di Indonesia. Salah satu karakterisitik yang mencolok dari karya Sadali ada pada pilihan bentuk dan warna pada karyanya. la kerap kali menggunakan kanvas-kanvas yg menampilkan warna gelap seperti warna tanah dan menggabungkan warna yang bertentangan dalam karyanya. Dapatkah Anda mengobservasi hal-hal tersebut pada karya ini"

TT: "Ahmad Sadali was a pioneer of modern abstract art in Indonesia. One of the most striking characteristics of his works could be seen through his choice of shapes and colors. He often uses canvases that display, dark colors such as earthy colors and combines several contrasting colors in his paintings. Can you observed these characteristics in this artwork?"

In (56), Evaluator 2 rates this caption as acceptable. ATA defines that the technical writing of the caption can be rated as acceptable if the translated text contains two errors such as grammar or spelling errors. The evaluator perceives that the grammar is not perfect but is still acceptable to read.

(61) ST: "Awal bulan ini, persembahan quartet dari @uphmusic menarik perhatian banyak pengunjung dan menuai pujian. Hari ini, mereka kembali dengan penampilan Orkestra Mini"

TT: "Earlier this month, the quartet performance from @uphmusic caught the attention of many visitors and gained praises. Today, they are back with a Mini Orchestra"

In (61), the Evaluator rates the caption as strong. ATA defines the idiomatic of caption can be rated as strong if the translated text can be read smoothly and the use of idioms is appropriate with the context. In this caption, the translated text can be read smoothly and it is appropriate to the context as we can see in the example. The translator has produced smooth translation result by using appropriate words in the translated text. The ST "Awal bulan ini, persembahan quartet dari.." is translated smoothly to "Earlier this month, the quartet performance from.." In this caption, there are translation shifts that occur. One of them is structure shift. Structure shift is identified in ST "Orkestra Mini" into TT "Mini Orchestra". The translator does shifts to produce a more accurate translation.

(69) ST: "Salah satu jurnalis legendaris Indonesia, Desi Anwar, berbincang dengan Director Museum MACAN Aaron Seeto untuk Insight, salah satu program unggulan di@cnnindonesia. Tunggu kabar kami tentang jadwal tayangnya!"

TT: "One of Indonesia's legendary journalists, Desi Anwar, talks to Director Aaron Seeto, for Insight, one of @cnnindonesia's signature programs. Stay tuned for updates on airing schedule!"

In this example, this caption is rated as strong by Evaluator 1. ATA has defined that the target mechanics can be considered as strong if the translated text fully follows the rules and conventions of target language mechanics which includes spelling, grammar, and punctuation. In this example, there is no misspelling that makes this caption is accurate. The grammar follows the rule which is the consistency of using tenses. The correct grammar can improve the translation result. In this study, level shift, intra-system shift and structure shift are helping translator to reach an accurate translation.

This can be inferred that translation shifts help the writer or translator of Museum MACAN's to produce an accurate translation. It is in line with Sipayung (2018) that states translation shift is used to reach an accurate translation and Trivanti (2017) that states translation shift helps translator to produce good translation. The writer and translator apply five types of translation shifts in their captions. The accurate captions produced by Museum MACAN's have higher possibility to be understood by English speakers all around the world and it also helps Museum MACAN to promote Indonesian culture and their art collection to the world.

ATA rubric assessment is reliable to be used in translation analysis. The dimensions in ATA rubric have covered all aspect of translation such as meaning, terminology, style and register, idiomatic, 
smoothness, grammar, punctuation and spelling. Another theory about translation accuracy is Nababan's theory. Nababan's theory of accuracy has already been used in several translation analyses. Since Nababan's theory has been used in several studies, This shows that Nababan's theory is credible in translation accuracy analysis. However, Nababan's theory (2003) is not as specific as ATA rubric assessment. Nababan only has three scales of accuracy which are accurate, inaccurate and not accurate. Meanwhile, ATA has four scales and five dimensions that have more details which can cover meaning, terminology, idiomatic, style and register, grammar, spelling and punctuation. Furthermore, Nababan's theory is more subjective compares to ATA rubric assessment because the basis of categorization in Nababan's theory (2003) lies on evaluator's personal perspective. Meanwhile, the basis of categorization in ATA rubric assessment has a more directed and clear standard in each dimension. From the finding results, the researcher concludes that translation shift improves translation results to be more accurate.

\section{CONCLUSION}

The translation shifts occurred in twenty five Museum MACAN's Instagram captions are 150 shifts consisting of level shift, structure shift, unit shift, class shift and intra-syestem shift. The most shift used is structure shift. It shows that the use of shifts helps writer or translator in adjusting words into an appropriate sentence from ST to TT. From the result of translation shifts analysis, it turns out that the application of translation shifts may improve the accuracy of a translation work. The accuracy of the caption is accurate based on three evaluators. The more accurate the captions are, the easier it is for English speakers all around the world to understand the meaning of a sentence correctly. This study also concludes that ATA rubric assessment is credible in analysing translation accuracy. ATA has standard criteria that cover translation aspects which are meaning, terminology, style and register, readability, grammar, spelling and punctuation. This study is expected to give contribution in translation analysing by giving information about translation shift. Also this study concluded that ATA rubric assessment is credible to be used in translation accuracy analysis. The findings of this study give information to Museum MACAN Instagram caption that their captions are accurate. Also Museum MACAN's decision to choose human translation rather than autotranslation is the right decision. This study suggests Museum MACAN to keep their quality of the captions to be better; therefore the information can be delivered well. 


\section{REFERENCE}

ATA. (2018). ATA (American Translators Association). Retrieved June 12, 2018, from https://www.atanet.org/aboutus/index.php

Azizah, Fitria Uswatun and Dr. Dwi Haryanti, M.Hum. (2017). An Analysis Of Category Shift Translation On Ani Yudhoyono's Instagram Captions In 2015. Retrived from http://eprints.ums.ac.id/55622/17/Halaman\%20depan-libraryums-fitria.pdf

Caption. (n.d). In Online Oxford Dictionaries. Retrieved from https://en.oxforddictionaries.com/definition/caption

Catford, J. C. (1978). A Linguistic Theory of Translation. Oxford: Oxford University Press,.

Demers, J. (2017). Why Instagram Is The Top Social Platform For Engagement (And How To Use It). Retrieved June 12, 2018, from https://www.forbes.com/sites/jaysondemers/2017/03/28/why-instagram-is-the-topsocial-platform-for-engagement-and-how-to-use-it/\#5f9356ad36bd

Jayanti, I. U. (2015). The Translation Procedure And Accuracy of Cultural Words in Short Story Ziarah Lebaran. Retrieved from http://repository.uinjkt.ac.id/dspace/bitstream/123456789/29217/3/IIn\%20Utama\%20 Jayanti-\%20FAH.pdf

KBBI. (2016). Pencarian - KBBI Daring. Retrieved June 12, 2018, from https://kbbi.kemdikbud.go.id/ 
Laksana, N, (2018). An Errors Types Analysis On Youtube Indonesia-English Auto-Translation In Kok Bisa? Channel. Retrieved from http://ejournal.usd.ac.id/index.php/JOLL/article/view/1058

Mobarakeh, M. D., \& Sardareh, S. A. (2016). The Effect of Translation Shifts on the Level of Readability of Two Pesian Translation of Novel "1984" by George Onwell. International Journal of Humanities and Cultural Studies (IJHCS). ISSN 2356-5926, 1418-1427.

Museum MACAN. (2017). About the Museum Museum MACAN. Retrieved June 12, 2018, from https://www.museummacan.org/about

Newmark, P. (1988). A Textbook of Translation. Text (Vol.66). New York: Prentice Hall.

Nugroho, A. B. (2007). Meaning and Translation. JEE, Journal of English and Education, 1(2). Retrieved from http://journal.uii.ac.id/JEE/article/view/6442

Oxford. (2018). English Dictionary, Thesaurus, \&amp; grammar help | Oxford Dictionaries. Retrieved June 12, 2018, from https://en.oxforddictionaries.com/

Sigma, T. (2016). Top Book SD Kelas V - Tim Sigma - Google Books. Retrieved June 12, 2018,

Sipayung, K. T. (2018). The Impact of Translation Shift and Method on Translation Accuracy Found at Bilingual History Textbook, 30(1), 58-66.

Trivianti, V. (2017). The Class Shift of Simple Sentence in English Indonesian Translation of The Stars Shine Down Novel. Retrieved from http://repository.uinjkt.ac.id/dspace/bitstream/123456789/34394/1/VANI\%20TRIVIANTIFAH.pdf

UNESCO. (2016). Indonesia | Diversity of Cultural Expressions. Retrieved June 12, 2018, from https://en.unesco.org/creativity/countries/indonesia

Wulandari, F. (2011). The Analysis Of Translation-shift Of The English Noun Phrase Used In The Garfield "Takes Up Space" Comic." Retrieved June 24, (2015).

Yuwandani, D. (2016). The Translation Shifts Applied To The Translated Text I Belog Lost Something, 23(44).

Zaro, J. J. (2002). Introducing Translation Studies. Theories and Applications. TRANS. Revista de Traductologia (Vol. 6). Retrieved August 29, (2017) 